\title{
Sciendo
}

DOI: 10.2478/orga-2019-0006

\section{The Influence of Competencies of Managers on Job Satisfaction of Employees in the Hotel Industry}

\author{
Mitja GORENAK, Tomi ŠPINDLER and Boštjan BRUMEN
}

University of Maribor, Faculty of Tourism, Cesta prvih borcev 36, 8250 Brežice, Slovenia, mitja.gorenak@um.si (corresponding author), tomi.spindler@um.si, bostjan.brumen@um.si

Background and purpose: The importance of soft-skills that managers can use to promote job satisfaction of employees is well known. Previous research has shown several different ways how managers can influence job satisfaction of employees, mostly in the form of external factors. Very little research is available on internal factors. This led us to the following research question: How managers' competencies influence job satisfaction of employees?

Design/Methodology/Approach: We have performed a pencil-paper survey among employees in the hotel industry sector. The questionnaire asked respondents to evaluate the competencies of their supervisors; later, we asked respondents to evaluate what influences their job satisfaction, and, in the final part, we collected some demographical data.

Results: The results show a weak, but still detectable, positive correlation between the competencies of managers and job satisfaction of employees in the factor that we have labelled "work itself". We have not found any correlation between the competencies of managers and job satisfaction of employees with regard to working conditions or possibilities of career development.

Conclusion: The competency of managers has an influence on job satisfaction of employees with regard to work itself. Although correlations that we have found are weak, they do exist, and have to be taken into account when it comes to discussing job satisfaction of employees. Managers who understand this core competency and promote it onwards to their employees will influence the job satisfaction of employees through this competency.

Keywords: competencies, managers, job satisfaction, influence, hotel industry.

\section{Introduction}

People are a key component of every organisation. When we are talking about the hotel sector (that fits into the broader Travel and Leisure sector), the importance of employees is even higher. On the one hand, we have seen successfully running fully automated hotels where guests have no interaction with actual employees (although such cases are rare); on the other hand, there is the importance of the so-called human touch within the Travel and Lei- sure industry that is increasing (Santos, Veiga, \& Águas, 2016). Another trend worth mentioning is the desire of customers to experience local products and services, with the emphasis being on the authenticity of the experience itself (Paulauskaite, Powell, Coca-Stefaniak, \& Morrison, 2017). There is no doubt that trends are changing, however, because when people come to a hotel they are expecting a warm welcome, hospitable behaviour, understanding of their needs, personalization of service and comfort (Ariffin \& Maghzi, 2012). Within the hotel industry customer satisfaction is going even further, as Torres and Kline (2013)

Received: September 18, 2018; revised: February 7, 2019; accepted: March 10, 2019 
suggest, it is moving towards customer delight, that includes taking care of the guests' needs, exceptional friendliness, professionalism of staff, employees going outside of the call of duty and problem-solving skills. In order to achieve such standards of care for guests, employees must experience job satisfaction themselves, since, as Lam and Chen (2012) suggest, job satisfaction of employees tends to increase their levels of service quality.

There have been many studies stating that job satisfaction is influenced by several different factors, such as: Work content (McPhail, Patiar, Herington, Creed, \& Davidson, 2015), pay and rewards (Sarwar \& Abugre, 2013), employee engagement (Yeh, 2013), work environment and conditions (Pan, 2015), career development possibilities (Ko, 2012), relationship with supervisors (Jang \& George, 2012) and leadership style (Kara, Uysal, Sirgy, \& Lee, 2013).

Although relationship with supervisors and leadership style have an influence on job satisfaction and is related directly to managers, no study has investigated the area of competencies of managers themselves. This brought us to the following research question: Is there any influence of competencies of managers on job satisfaction of employees?

We decided to conduct the study within the hotel industry for two reasons; firstly, the hotel industry is a substantial part of the Slovenian Travel and Leisure industry. The Travel and Leisure industry is on the rise, and currently presents indirectly about $12 \%$ of total GDP, and employs one out of every ten employees within the sector; secondly, there is an indication in a recent study by Golubovskaya, Robinson, and Solnet (2017) that has shown that: »a hospitality workforce tends to favour service management and service processes as the guiding paradigm. The essence of what it means to be hospitable, and the host-guest model, appears to be largely absent in practice«. This finding shows a gap between trends on one side and standards employees within the same sector prefer to operate by.

\section{Literature review}

Based on the stated research question, we conducted a more in-depth review of literature about two key segments: Competencies and job satisfaction.

\subsection{Competencies}

Competencies have been one of the focal points of discussion within Human Resources Management for the past two decades. They can be found in different textbooks (Bratton \& Gold, 2012; Snell, Morris, \& Bohlander, 2015) provided for scholars and academics, as well as books intended for managerial use (Collins \& Porras, 2005; Prahalad \& Hamel, 2006). One of the first discussions about competencies was made in the mid-1970s, when it was proposed to test people for their competencies rather than their intelligence (McClelland, 1973). In this sense, competencies were defined as knowledge that an individual has gained (McClelland, 1998). Understanding of competencies evolved through time, and various researchers added additional content to competencies. An overview is shown in Table 1.

Competencies are being reflected in the behaviour of individuals. Behaviour, in turn, is the result of individuals' upbringing (Dunleavy, Milton, \& Crawford, 2010), knowledge (Snell et al., 2015) and experiences (Bratton \&

Table 1: Views on competencies through time.

Competencies are a mixture of individuals' motives, abilities, self-image, social role and knowledge that a person uses in social interactions.

Competencies are not just the (Hartle, 1995) knowledge, but also personal characteristics that have evolved through the educational process and were shaped further by work in an organisation.

Competency is an individual's demonstrated knowledge, skills, or ability.

Brockbank, Yeung, \& Lake, 1995)

Competencies are individuals' be- (van Klink \& haviours in a certain situation. $\quad$ Boon, 2003)

A competency is defined as a capa- $\quad$ (Boyatzis, 2008) bility or ability.

"Competency" is a commonly used term for people's asserting of their working potential in real activities.

Competence is seen as something (Luthar \& Trdigrounded in an idealised reconstruc- na, 2015) tion of childhood and upbringing, education, and family values.

Gold, 2012), thus, we can say that competencies are being reflected in the behaviour of individuals.

In the Travel and Leisure industry, competencies are, in some cases, understood as a mixture of soft skills that were found to be among the most important competencies in this sector (Christou, 2002), behavioural skills, generic attributes (Spowart, 2011). All these are of extreme importance for the employees in the Travel and Leisure industry (Moolman \& Wilkinson, 2014).

Chung-Herrera, Enz, and Lankau (2003) explored the 
required competencies of successful leaders in the Travel and Leisure industry, and listed 99 competency items, 28 competency dimensions, and 8 factors. In order of importance, the factors include self-management, strategic positioning, implementation, communication skills, relationships, leadership, and industrial knowledge.

Potočnik Topler (2017) stresses the importance of linguistics competence as a part of a communication skills set for the positive perception of a destination by customers. Many of these competencies can be labelled as "soft-skills". The importance of soft skills in managing Human Resources in the Travel and Leisure industry was researched by (Spowart, 2011). They (he) proposed four categories of soft skills that can be identified and also related to competencies' clusters that managers need for performing their jobs. These are: (1) Leadership/people/ relationship skills, (2) Communication, (3) Management and organisation and (4) Cognitive skills and knowledge.

Very similarly, (Wong \& Lee, 2017) identified that commitment and awareness of quality are two of the most important competencies within Human Resources management in the Travel and leisure industry. With sustainability being a very important concept within the Travel and Leisure industry, it is seen as an important competence (Pereira, 2017).

Based on the related research, we can conclude that competencies are a mixture of knowledge, abilities, skills, experiences, and values of an individual gathered during their primary socialization, various levels of education and work life.

\subsection{Job satisfaction}

In the second part of this literature overview we are focusing on job satisfaction of employees. Job satisfaction is seen as an individual's perception of his or her experiences with the company as a whole, part of the company, company procedures and fellow employees (Vroom, 1957). Another commonly used definition of job satisfaction sees it simply as how content an individual is with her job; simply whether she likes the job or not (Spector, 1997).

Understanding of job satisfaction evolved through time, and various researchers highlighted various aspects of it. An overview is shown in Table 2.

The importance of job satisfaction within a service sector such as the hotel industry is very clear, since the nature of service delivery means that the human element has a relevant role in achieving excellence, and, therefore, the satisfaction of employees is a must (Nogueira Novaes Southgate \& Mondo, 2017). While job satisfaction has a positive influence on standard performance (Rich, Lepine, \& Crawford, 2010), we have seen research stating that job satisfaction does not necessarily lead to employees' willingness to exert extra effort (Kim \& Brymer, 2011).
Table 2: Views on job satisfaction through time.

\begin{tabular}{l|l|}
\hline $\begin{array}{l}\text { Job satisfaction is a pleasura- } \\
\text { ble or positive emotional state } \\
\text { resulting from the appraisal of } \\
\text { one's job or job experiences. }\end{array}$ & (Locke, 1976) \\
\hline $\begin{array}{l}\text { Simply stated, the more a per- } \\
\text { son's work environment ful- } \\
\text { fils his or her needs, values, } \\
\text { or personal characteristics, the } \\
\text { greater the degree of job satis- } \\
\text { faction. }\end{array}$ & $\begin{array}{l}\text { (Ellickson \& Logs- } \\
\text { don, 2002) }\end{array}$ \\
\hline $\begin{array}{l}\text { Job satisfaction is a psycholog- } \\
\text { ical response to one's job that } \\
\text { includes cognitive, affective } \\
\text { and behavioural components. }\end{array}$ & (Hulin \& Judge, 2003) \\
\hline $\begin{array}{l}\text { Job satisfaction refers to sat- } \\
\text { isfaction with everyday work } \\
\text { tasks and conditions. }\end{array}$ & (Christen, Iyer, \& So- \\
\hline $\begin{array}{l}\text { The term job satisfaction refers } \\
\text { to the attitude and feelings peo- } \\
\text { ple have about their work. }\end{array}$ & (Armstrong \& Taylor, \\
\hline $\begin{array}{l}\text { Job satisfaction can also be } \\
\text { seen as a range of issues which } \\
\text { affect an individual's experi- } \\
\text { ence of work, or their quality of } \\
\text { working life. }\end{array}$ & (Tomaževič, Seljak, \& \\
\hline $\begin{array}{l}\text { Job satisfaction was defined as } \\
\text { satisfaction with the intrinsic } \\
\text { and extrinsic aspects of the em- } \\
\text { ployees` role. }\end{array}$ & $\begin{array}{l}\text { (Tongchaiprasit } \\
\text { Ariyabuddhiphongs, }\end{array}$ \\
2016) \\
\hline
\end{tabular}

Researchers have determined many different factors that influence job satisfaction. Furnham (1994) suggests that we should not talk about individual factors, but rather about groups of factors. In the first group, there are factors related to organisational behaviour, such as: Management systems, decision-making procedures, system of promotions and rewards. In the second group, there are factors related to job specifics, such as: Autonomy at work, use of specific knowledge and information feedback. In the last, third group, there are factors related to individuals' characteristics, such as: Self-esteem, stress management and ability of critical thinking. Different factors were identified as the ones affecting job satisfaction. We have focused on research within the broader sector of Travel and Leisure. In this sector, Tutuncu and Kozak (2007) identified work itself as the primary factor affecting job satisfaction, and career development as another very important factor, while Yeh (2013) identified working conditions as a factor of major importance to job satisfaction. 
To summarise the literature review, job satisfaction is an emotional state of an individual that is influenced by numerous factors that are affected by the individual's experience of work, their quality of working life, and other characteristics related to how their work is being managed.

\section{Research question and hypotheses}

The research question is whether there is any influence of competencies of managers on job satisfaction of employees?

In order to answer this research question, the following research hypotheses were set up based on the knowledge gained in the theoretical overview:

H1: There is no statistically significant influence of competencies of managers on job satisfaction of employees with regard to satisfaction with the work itself.

$\mathrm{H} 2$ : There is no statistically significant influence of competencies of managers on job satisfaction of employees with regard to satisfaction with working conditions.

H3: There is no statistically significant influence of competencies of managers on job satisfaction of employees with regard to satisfaction with the possibilities of career development.

We are basing our research question, as well as the hypotheses, on the existing link between competencies and job satisfaction. A study (Çetin, Karabay, \& Efe, 2012) has shown that negative leader-employee interactions that are based on knowledge skills and abilities we could call them competencies of managers - present stress for the employees, and so create job dissatisfaction. However, we cannot say that there is only a negative side to it. A study has shown that different leadership styles can have positive influence on job satisfaction (Voon, Lo, Ngui, \& Ayob, 2011), and, since it is proven that leadership styles are influenced by the competencies of leaders (Müller \& Turner, 2010), we can see the influence of leadership styles on job satisfaction of employees. There is also the issue of career development being discussed by (Kong, Cheung, \& Song, 2012), who have found a link between career competency and career development satisfaction.

\section{Research methodology}

\subsection{Sample and instrument}

The population of the selected sector (hotel industry) was determined by the data of Republic of Slovenia Statistical Office: A total of $\mathrm{N}=9,117$ persons were employed in 2013 in Slovenia's hotel industry (STAT.SI, 2013), the same year that the research was conducted. Someone might argue that the data are relatively old; however, since there was no major technological or other change in society, data are not obsolete, thus, they are still appropriate for use. In order to get relevant representation of this sample, we have decided to use random sampling of organisations. We have created a list of organisations for each region in the country, and then selected every 5th organisation, and asked them to participate in the survey. We have been granted consent by several organisations that employ a total of 2,762 people. We distributed in total 1,100 pencil-paper questionnaires between randomly selected employees; for this purpose, we used a simple random sampling method. All the organisations asked to participate in the survey were selected randomly within the sector, making sure that, geographically, we covered the entire country. Within the 60-day period set for the survey, 388 out of 1,100 questionnaires were returned, which represents $35.27 \%$ of all questionnaires sent out, and $4.26 \%$ of the entire population.

Before the questionnaire was administered on the full scale, we tested it on a smaller sample and made appropriate modifications.

In the first part, there were 48 statements regarding competencies of managers - this part was self-created based on competencies defined by the Slovenian Institute for Vocational Training (a list of competencies for Hotel Managers). In the second part, there were 25 statements regarding job satisfaction - in this part, we used a pre-existing questionnaire by Mihalič (2008), where the only change we made was the use of a 5 stage scale (from 1 - I do not agree at all, to 5 - I fully agree; 2,3 and 4 presented the in-between values). Next to that, we also collected some demographical data of respondents, such as age, gender, and level of education.

Some statements were created intentionally in a negative form to test the respondent's attention. Before we conducted analyses, we recoded the values of these variables appropriately, although the text remained the same. Next , we also collected some demographical data of respondents, such as age, gender, and level of education.

\subsection{Data analyses}

The data were analysed using SPSS version 21 (IBM Corporation, Armonk, NY, USA). We considered differences to be significant at $\alpha<0.05$ level, with Bonferroni correction where applicable. 


\section{Results}

\subsection{Demographic results}

The sample which was used for the purpose of this paper contained 133 (34.3\%) male respondents and $213(54.9 \%)$ female respondents, and $42(10.8 \%)$ people who did not respond to the question regarding gender. The average age of respondents was calculated at 38.17 years of age. The sample contained $34(8.8 \%)$ respondents with completed elementary school or less, $83(21.4 \%)$ respondents with vocational high school, 121 (31.4\%) respondents with high school, $80(20.6 \%)$ respondents with a college degree, 35 $(9.0 \%)$ respondents with a university degree or more, and $35(9.0 \%)$ respondents who decided not to disclose their level of education.

\subsection{Sample validity and reliability}

In order to be able to generalise the results to the entire population, we first performed tests to establish the validity of the sample. For this step, we did the chi-square test of significance on the demographic information data that we had for population, as well as for the sample. These were: Gender, education and age. For the variable gender, (one degree of freedom) chi-square was calculated at 0.598 , and significance level at $p=0.434$, for the variable education (four degrees of freedom), the chi-square test value was calculated at 9.296 with significance level at $p=0.054$, the final variable age (seven degrees of freedom) provided a value of 13.971, and the level of significance was at $p$ $=0.052$. Based on the findings, we can conclude that the research sample could be generalised to the whole population (Spruill, 1976).

For the next step, we tested the reliability of the questionnaire using the Cronbach's alpha test, calculating the coefficients for the set of variables. We performed this test on variables that measured values, and calculated the value of 0.859 . This value indicates great reliability of measurement (Cronbach, 1951).

Based on the tests, we can conclude that our sample is representative of the population of employees in the Slovenian hotel sector, and of sufficient reliability.

\subsection{Factor analysis}

Before actually conducting the factor analysis of variables related to competencies we performed a Kaiser-Meyer-Olkin (KMO) measure of sampling adequacy, and Bartlett's test of sphericity. The results show KMO value of 0,950 and significance of 0,000 for Bartlett's test of sphericity, thus indicating the appropriateness of the sample for factor analysis.

In the first step, we conducted a factor analysis on the set of the first 48 variables that measured competencies. Out of 48 variables, 30 of them had positioned themselves in 6 different factors with suitable weights, while the other 18 had either not positioned in any of the factors, or had a minimum weight in two or more factors. That is why we have removed them. With the help of factor analysis, we were able to explain $54.96 \%$ of variability of competencies with 30 variables in 6 factors. Results are shown in Table 3.

Based on the factor analysis we have determined six different factors, in factor one variables such as: my manager communicates with customers respectfully, my manager supervises compliance of external and internal regulations, my manager monitors the results of the organisational unit, and several others were positioned. These variables indicated responsible behaviour, thus we have decided to name this factor CR - Competencies Responsibility. In the second factor variables such as: disrespectful communication with employees is typical for my manager, immoral conduct is typical for my manager, my manager's conduct creates a negative atmosphere and several others were positioned. These variables indicated ethical behaviour, thus we have decided to name this factor CE Competencies Ethics. In the third factor variables such as: encouraging changes to the procedures at work are typical for my manager, my manager monitors the implementation of tasks, my manager resolves demanding complaints professionall, and several others were positioned. These variables indicated innovative behaviour, thus we have decided to name this factor CI - Competencies Innovation. In the foruth factor variables such as: my manager does not supervise the work process, my manager does not control the quality of performed work, my manager orders the work of employees irresponsibly and several others were positioned. These variables indicated quality oriented behaviour, thus we have decided to name this factor CQ Competencies Quality. In the fifth factor variables such as: providing instruction to new employees at work is typical for my manager, my manager participates as a mentor to new employees, my manager advises employees at work and some others were positioned. These variables indicated emmployee oriented behaviour, thus we have decided to name this factor CEm - Competencies Employees. In the final sixth factor variables: my manager prepares special market outlets, my manager monitors customer loyalty and my manager monitors supply on the market were positioned. These variables indicated customer oriented behaviour, thus we have decided to name this factor CC Competencies Customers. 
Table 3: Factor analysis of variables that measured competencies

\begin{tabular}{|c|c|c|c|c|c|c|}
\hline \multirow[t]{2}{*}{ Variable } & \multicolumn{6}{|c|}{ Factor } \\
\hline & 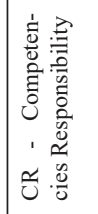 & 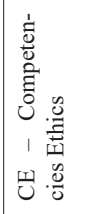 & 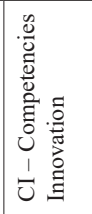 & 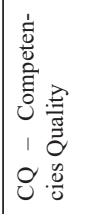 & 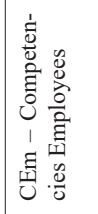 & 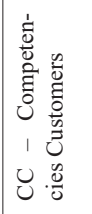 \\
\hline My manager communicates with customers respectfully. & .719 & & & & & \\
\hline $\begin{array}{l}\text { My manager supervises compliance of external and internal regula- } \\
\text { tions. }\end{array}$ & .544 & & & & & \\
\hline My manager monitors the results of the organisational unit. & .516 & & & & & \\
\hline $\begin{array}{l}\text { My manager works in accordance with the environmental protection } \\
\text { measures. }\end{array}$ & .509 & & & & & \\
\hline $\begin{array}{l}\text { My manager distributes the work of subordinates according to work- } \\
\text { load. }\end{array}$ & .487 & & & & & \\
\hline My manager takes care of the importance of contacts with customers. & .481 & & & & & \\
\hline $\begin{array}{l}\text { My manager takes care to ensure rational use of energy, materials and } \\
\text { time. }\end{array}$ & .455 & & & & & \\
\hline $\begin{array}{l}\text { Disrespectful communication with employees is typical for my man- } \\
\text { ager. }\end{array}$ & & .696 & & & & \\
\hline Immoral conduct is typical for my manager. & & .581 & & & & \\
\hline My manager's conduct creates a negative atmosphere. & & .580 & & & & \\
\hline My manager fails to ensure good relationships with customers. & & .538 & & & & \\
\hline My manager has a discriminatory attitude towards employees. & & .494 & & & & \\
\hline $\begin{array}{l}\text { Encouraging changes to the procedures at work are typical for my } \\
\text { manager. }\end{array}$ & & & .652 & & & \\
\hline My manager monitors the implementation of tasks. & & & .495 & & & \\
\hline My manager resolves demanding complaints professionally. & & & .474 & & & \\
\hline My manager encourages employees to perform better at work. & & & .465 & & & \\
\hline Timely identification of new forms of work is typical of my manager. & & & .443 & & & \\
\hline My manager does not supervise the work process. & & & & .771 & & \\
\hline My manager does not control the quality of performed work. & & & & .566 & & \\
\hline My manager orders the work of employees irresponsibly. & & & & .506 & & \\
\hline My manager is not able to deal with tasks in a timely manner. & & & & .467 & & \\
\hline My manager is unprofessional at organisation of work within the unit. & & & & .456 & & \\
\hline $\begin{array}{l}\text { Providing instruction to new employees at work is typical for my man- } \\
\text { ager. }\end{array}$ & & & & & .802 & \\
\hline My manager participates as a mentor to new employees. & & & & & .702 & \\
\hline My manager advises employees at work. & & & & & .653 & \\
\hline $\begin{array}{l}\text { Caring for the continuous development of employees is typical of my } \\
\text { manager. }\end{array}$ & & & & & .539 & \\
\hline $\begin{array}{l}\text { Resolving the concrete problems in the process is the nature of my } \\
\text { manager. }\end{array}$ & & & & & .466 & \\
\hline My manager prepares special market outlets (discounts, credits, etc .) & & & & & & .465 \\
\hline My manager monitors customer loyalty. & & & & & & .374 \\
\hline My manager monitors supply on the market. & & & & & & .351 \\
\hline
\end{tabular}


Table 4: Factor analysis of variables that measured job satisfaction.

\begin{tabular}{|c|c|c|c|}
\hline Variable & \multicolumn{3}{|c|}{ Factor } \\
\hline My job satisfaction is influenced by ... & 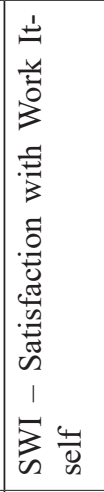 & 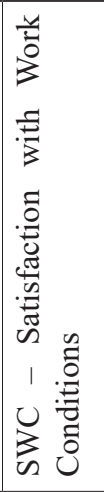 & 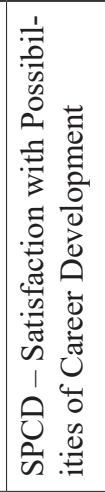 \\
\hline ... My work challenges. & .828 & & \\
\hline ... Forms of motivation that my manager uses. & .820 & & \\
\hline ... Possibility to develop my competencies. & .749 & & \\
\hline ... Interpersonal relationships within the organisation. & .706 & & \\
\hline ... Strict discipline within the organisation. & .706 & & \\
\hline ... Professionalism at work. & .687 & & \\
\hline ... Possibilities to co-create decisions within the organisation. & .671 & & \\
\hline ... Caring for my well-being in the organisation. & .653 & & \\
\hline ... Feedback that I get regarding my work. & .606 & & \\
\hline ... Status that I have within the organisation. & .514 & & \\
\hline ... Possibilities of creative work. & .477 & & \\
\hline ... Intensity of rewarding that I am receiving. & .426 & & \\
\hline ... Possibilities for improving my level of education. & .422 & & \\
\hline ... The amount of work I do. & & .852 & \\
\hline ... Working hours that I have. & & .821 & \\
\hline ... Leadership style of my manager. & & .656 & \\
\hline ... Type of work I do. & & 653 & \\
\hline ... My immediate co-workers. & & .550 & \\
\hline ... Physical working conditions. & & .458 & \\
\hline ... Level of safety and security of my job. & & .442 & \\
\hline ... Work space where I work. & & .357 & \\
\hline ... Pay that I receive. & & .349 & \\
\hline ... Manager`s efforts for my career development. & & & -.843 \\
\hline ... Possibilities of career development. & & & -.735 \\
\hline ... Health and safety at work. & & & -.411 \\
\hline
\end{tabular}


We performed the Kaiser-Meyer-Olkin (KMO) measure of sampling adequacy and Bartlett's test of sphericity on 25 variables from the second part of the questionnaire related to job satisfaction. The results show a KMO value of 0,961 and significance of 0,000 for Bartlett's test of sphericity, thus indicating that the sample is appropriate for factor analysis. All 25 variables had positioned themselves in one of the three factors. We were able to explain $56.23 \%$ of variability of competencies with these 25 variables in 3 factors. Results are shown in Table 4.

Based on the factor analysis we have determined three different factors, in factor one we can see variables influencing job satisfaction such as: my work challenges, forms of motivation that my manager uses, possibility to develop my competencies and several more. These variables describe the content of work, thus we have decided to name this factor SWI - Satisfaction with Work Itself. In the second factor we can see variables influencing job satisfaction such as: the amount of work I do, working hours that I have, leadership style of my manager and few others. These variables describe working conditons, thus we have decided to name this factor SWC - Satisfaction with Work Conditions. In the final third factor we can see the following variables influencing job satisfaction: manager's efforts for my career development, possibilities of career development and health and safety at work. These variables describe how satisfied employees are with career development possibilities, thus we have decided to name this factor SPCD - Satisfaction with Possibilities of Career Development.

\subsection{Correlation analysis}

Further interest was related to measuring the correlation between merged variables of competencies of managers and job satisfaction, therefore, Pearson's correlation coefficient was used. Results are shown in Table 5.

Among data shown in Table 5, we can see that there is a weak correlation between all six groups of competencies and the newly formed variable SWI - Satisfaction with Work Itself. Both of the other job satisfaction variables did not show any correlation with variables representing competencies. From Table 5? it is clear that the existing correlations are positive, though weak (Cohen, 1988). The highest recorded correlation was between CC - Competencies Customers and SWI - Satisfaction with Work Itself, this was measured at 0.204 .

Since correlation studies only show correlations between the before mentioned variables, but not the numerical relation between variables, we proceeded with the linear regression analysis to understand better the internals of the connection.

\subsection{Linear regression analysis}

We conducted a linear regression analysis, where the influence was analysed between independent variables and dependent variables. The influence of each of the independent variables was evaluated, so that it is not dependent on influences between various independent variables. Table 6 presents the values of regression among pairs of independent variables (competencies) and dependent variables (Satisfaction with Work Itself).

Table 6 shows the results of linear regression. All the pairs have shown statistically significant influence $(p<0.05)$. In the first pair, we put together independent variable "CQ - Competencies Quality" and dependent variable "SWI - Satisfaction with Work Itself". The results $\left(\Delta \mathrm{R}^{2}=0.017 ; \mathrm{F}=6.757 ; \mathrm{p}=0.010\right)$ show that, with variable "CQ - Competencies Quality", we can explain $1.7 \%$ of variability for "SWI - Satisfaction with Work Itself". In the second pair, we put together the independent variable "CI - Competencies Innovation" and dependent variable "SWI - Satisfaction with Work Itself". The results $(\Delta \mathrm{R} 2=0.016$; $\mathrm{F}=6.485 ; \mathrm{p}=0.011$ ) show that with, variable " $\mathrm{CI}-\mathrm{Com}-$ petencies Innovation", we can explain $1.6 \%$ of variability for "SWI - Satisfaction with Work Itself". In the third pair, we put together independent variable " $\mathrm{CR}$ - Competencies Responsibility" and dependent variable "SWI - Satisfaction with Work Itself". The results $\left(\Delta \mathrm{R}^{2}=0.020 ; \mathrm{F}=7.520\right.$; $\mathrm{p}=0.006)$ show that, with variable " $\mathrm{CR}-$ Competencies Responsibility", we can explain $2.0 \%$ of variability for "SWI - Satisfaction with Work Itself". In the fourth pair, we put together independent variable " $\mathrm{CE}$ - Competencies Ethics" and dependent variable "SWI - Satisfaction with Work Itself". The results $\left(\Delta \mathrm{R}^{2}=0.027 ; \mathrm{F}=8.920 ; \mathrm{p}=0.003\right)$ show that, with variable " $\mathrm{CE}$ - Competencies Ethics", we can explain $2.7 \%$ of variability for "SWI - Satisfaction with Work Itself". In the fifth pair, we put together the independent variable "CC - Competencies Customers" and dependent variable "SWI - Satisfaction with Work Itself". The results $\left(\Delta R^{2}=0.042 ; F=13.932 ; p=0.000\right)$ show that with variable "CC - Competencies Customers" we can explain $4.2 \%$ of variability for "SWI - Satisfaction with Work Itself". In the final, sixth pair, we put together the independent variable "CC - Competencies Employees" and dependent variable "SWI - Satisfaction with Work Itself". The results $\left(\Delta \mathrm{R}^{2}=0.013 ; \mathrm{F}=4.471 ; \mathrm{p}=0.035\right)$ show that, with variable "CEm - Competencies Employees", we can explain $1.3 \%$ of variability for "SWI - Satisfaction with Work Itself". Results are shown in Figure 1. 
Table 5: Correlation between individual merged variables.

\begin{tabular}{|c|c|c|c|c|c|c|}
\hline & 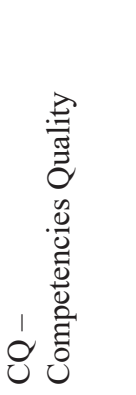 & 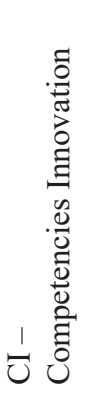 & 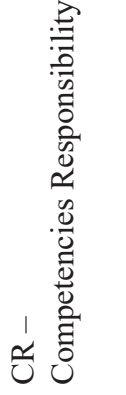 & 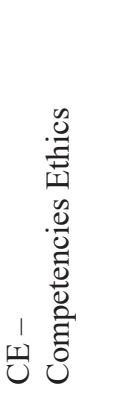 & 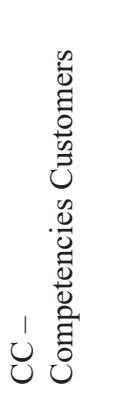 & 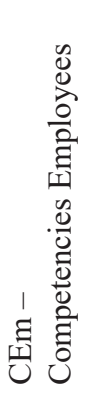 \\
\hline SWI - Satisfaction with Work Itself & $0.143 * *$ & $0.139 *$ & $0.150 * *$ & $0.163 * *$ & $0.204 * *$ & $0.116^{*}$ \\
\hline SWC - Satisfaction with Work Conditions & 0.021 & 0.010 & 0.064 & 0.053 & 0.052 & -0.004 \\
\hline $\begin{array}{l}\text { SPCD - Satisfaction with Possibilities of Career } \\
\text { Development }\end{array}$ & -0.009 & 0.007 & -0.021 & -0.028 & -0.069 & -0.002 \\
\hline
\end{tabular}

* Correlation is significant at the 0.05 level (2-tailed).

** Correlation is significant at the 0.01 level (2-tailed).

Table 6: Regression analysis between competencies and Satisfaction with Work Itself.

\begin{tabular}{|c|c|c|c|}
\hline $\begin{array}{c}\text { Regression - Organisational competencies - Satisfac- } \\
\text { tion with Work Itself }\end{array}$ & $\mathbf{\Delta \mathbf { R } ^ { \mathbf { 2 } }}$ & $\mathbf{F}$ & $\mathbf{P}$ \\
\hline CQ - Competencies Quality & .017 & 6.757 & 0.010 \\
\hline CI - Competencies Innovation & .016 & 6.485 & 0.011 \\
\hline CR - Competencies Responsibility & .020 & 7.520 & 0.006 \\
\hline CE - Competencies Ethics & .027 & 8.920 & 0.003 \\
\hline CC - Competencies Customers & .042 & 13.932 & 0.000 \\
\hline CEm - Competencies Employees & .013 & 4.471 & 0.035 \\
\hline
\end{tabular}

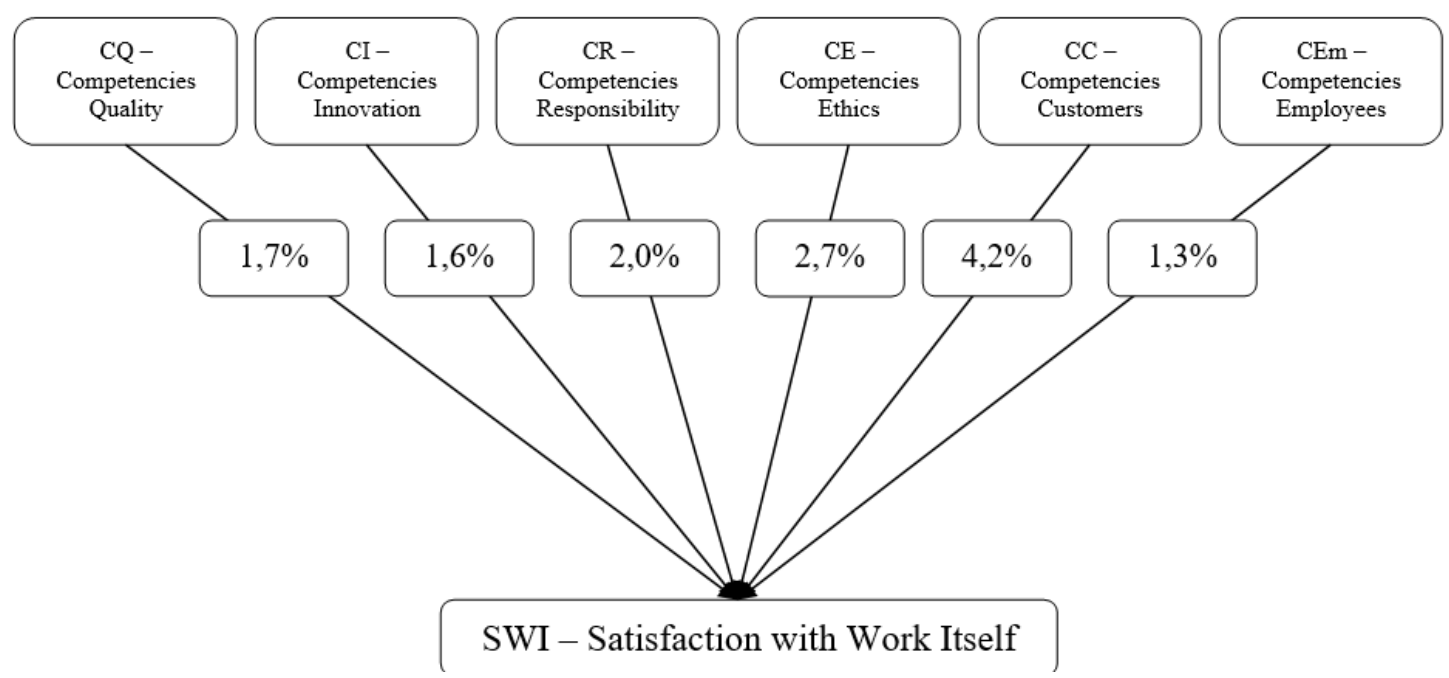

Figure 1: Linear regression model with results 


\section{Discussion}

Based on the findings, we can reject the first hypothesis H1: There is no statistically significant influence of competencies of managers on job satisfaction of employees with regard to satisfaction with work itself. There is a clear, although weak, correlation between competencies of managers and job satisfaction (satisfaction with work itself).

On the other hand, we have found no correlation between competencies of managers and either of the other two job satisfaction factors, satisfaction with working conditions and satisfaction with possibilities of career development, thus we have to retain both $\mathrm{H} 2$ and $\mathrm{H} 3$ as there is no statistically significant influence of competencies of managers on job satisfaction of employees with regard to satisfaction with working conditions and with regard to possibilities of career development, respectively.

The answer to our research question: "Is there is any influence of the competencies of managers on job satisfaction of employees?", is "yes, partially". It is so only when it comes to job satisfaction related to the work itself.

We have found significant correlation between managerial competencies and employees' satisfaction with work itself. Competencies include the following aspects: Competencies Quality, Competencies Innovation, Competencies Responsibility, Competencies Ethics, Competencies Customers and Competencies Employees.

Each of these aspects were researched previously:

- Competencies Quality: Noe, Hollenbeck, Gerhart, and Wright (2006) found that employees who are being supported in providing high quality service are showing higher levels of job satisfaction.

- Competencies Innovation: Lok and Crawford (2004) have determined that promotion of innovative culture leads to job satisfaction; Uran Maravić, Križaj, and Lesjak (2015) stated: "innovation is, because of its uniqueness and exclusivity, an important factor in economic development, and may represent a key competitive advantage for a tourism organisation or tourist destination".

- Competencies Responsibility: Valentine (2001) determined that employees who perceive greater responsibility may, therefore, be more satisfied with their jobs.

- Competencies Ethics: Okpara and Wynn (2008) determined that ethical climate types (caring, rules, instrumental, efficiency) have a significant positive impact on various facets of job satisfaction.

- Competencies Customers: Noe et al. (2006) claim that managers with focus on customers will create more satisfied customers and, thus, also making employees satisfied with their work when dealing with high quality customer service that makes customers satisfied.

- Competencies Employees: Lee and Bruvold (2003) claim that employees will be more satisfied with the job and more affectively committed to an organisation when the employer commits to developing employees.

Our results are unique, because we have shown in a single research that all these competencies are interrelated, and influence the satisfaction with work itself significantly. Additionally, we have shown that two other factors, satisfaction with working conditions and satisfaction with possibilities of career development, are not correlated to managerial competencies.

Our research had certain limitations. Firstly, while it is true that a questionnaire is the most appropriate tool for conducting research of this type, there is very little room for in-depth knowledge on certain subjects when using a structured questionnaire. Another limitation of this research is also the sample being limited to the hotel sector only. It is not certain whether research in a different sector would provide different results. At this point, however, we need to stress the validity of the research made in this single sector, and conclude that results can indeed be generalised if the selected sector is not specifically denoted by population assumptions (Hannan \& Freeman, 1977). Another limitation to this research lies in the fact that it was conducted in a single country, hence, results may vary by different countries. All the limitations mentioned above are also suitable grounds for further research. Another possibility of further research would be focusing only on job satisfaction with work itself i.e. with variables that describe the content of work as shown in our research.

\section{Conclusion}

The importance of soft skills that managers can use to promote job satisfaction of employees is well known. Previous research has shown several different ways in which managers can influence job satisfaction of employees, mostly in the form of external factors. In the present work, we investigated if and how internal factors of managerial competencies influence job satisfaction and its three constituent parts, satisfaction with work itself, satisfaction with work conditions, and satisfaction with the possibilities of career development.

Our contribution has shown that competency of managers has an influence on job satisfaction of employees with regard to job satisfaction with work itself, but not with the other two factors (work conditions, career development).

The novelty of our research is two-fold. First, we have shown that managerial competencies do not influence all aspects of work satisfaction. Secondly, satisfaction with work itself can be explained mostly by managerial competencies with respect to customers. This is highly important in the hotel sector, because it is very much customer oriented and dependent.

Although correlations are weak, they do exist, and have to be taken into account when it comes to discussing 
job satisfaction of employees. The highest recorded correlation was between competencies-customers and satisfaction with work itself (0.204). We firmly believe that this indicates that employees value very much the competencies of managers who promote the core idea of hospitality, i.e. taking care of customers. This also shows that employees understand the importance of hospitality for customers, and this provides them with their own job satisfaction.

The results clearly support the theoretical conceptualizations that managing job satisfaction of employees is important. This is even more critical within the hotel sector, since employees are in direct contact with customers. The hotel sector is, in this sense, even more vulnerable. Customers are seeking services that make them feel at ease and relaxed, and, with competition in the sector being fierce, managers must pay attention to all the small details that can make their guests enjoy their experience. For years we have lived with the idea that the customer is the king or queen, but, if managers treat their employees well and seek every opportunity to enhance job satisfaction of employees, these same employees will treat customers not only as kings or queens, but truly as royalty.

In practice many managers tend to favour investing their resources into factors that would provide satisfaction with working conditions in some cases even satisfaction with possibilities of career development, while forgetting that factors influencing job satisfaction related to work itself are also important. What we have shown through our research is, that work itself is the important component of job satisfaction and investing resources to make work itself interesting for employees' should be on the top or any managers list since based on our results it does have the highest impact on job satisfaction of employees.

Among all variables influencing job satisfaction with work itself we have seen work challenges of employee, managers must try to create work, itself full of challenges, while using appropriate means of motivating employees and allowing them to develop their competencies, since this will increase their value. It is also important for the managers to build good interpersonal relationships within the organisation and enforce reasonably strict discipline since this will help promote professionalism at work. For many people professionalism represents the meaning of work, they want to feel that their work matters. The feeling of being valuable to organization is very important for employee's managers must thus help include employees in decision making processes where that is possible since this will further increase their job satisfaction.

It is very important for practitioners to understand how important satisfaction with work itself is within the context of job satisfaction of employees. With the amount of time we are spending at work it is no doubt that any manager needs to use all the knowledge he or she has to help increase the job satisfaction of employees, this being even more important in service oriented industries.

Further research that we propose is to investigate job satisfaction among "employees" that manage their own apartments through platforms such as AirBnb, and we have to understand that jobs themselves are changing, Turnšek and Ladkin (2017) did extensive work on Airbnb that has hit the hotel sector hard in recent years, and noted that job satisfaction within the sharing economy, or platform economy, has a completely different position, that is why we propose this as an interesting area to conduct research in.

We have to understand that, not even the best managers can be overseeing how their employees treat their customers all the time. Thus, it is even more important that they can rely on their employees to provide the experience of hospitality for customers at every step of the way, since, as is seen by Rangus and Brumen (2016), the importance of tourism is, after all, visible in its huge impact on the local, national and global economies.

\section{Literature}

Ariffin, A. A. M., \& Maghzi, A. (2012). A preliminary study on customer expectations of hotel hospitality: Influences of personal and hotel factors. International Journal of Hospitality Management, 31(1), 191-198, https://10.1016/j.ijhm.2011.04.012

Armstrong, M., \& Taylor, S. (2014). Armstrong's Handbook of Human Resource Management Practice: Kogan Page Publishers.

Boyatzis, R. E. (1982). The Competent Manager: A Model for Effective Performance: John Wiley \& Sons.

Boyatzis, R. E. (2008). Competencies in the 21 st century. Journal of Management Development, 27(1), 5-12.

Bratton, J., \& Gold, J. (2012). Human Resource Management: Theory and Practice: Palgrave Macmillan.

Çetin, M., Karabay, M. E., \& Efe, M. N. (2012). The effects of leadership styles and the communication competency of bank managers on the employee's job satisfaction: the case of Turkish banks. Procedia-Social and Behavioral Sciences, 58, 227-235, https://doi.org/10.1016/j.sbspro.2012.09.996

Christen, M., Iyer, G., \& Soberman, D. (2006). Job satisfaction, job performance, and effort: A reexamination using agency theory. Journal of Marketing, 70(1), 137150, https://doi/10.1509/jmkg.2006.70.1.137

Christou, E. (2002). Revisiting competencies for hospitality management: Contemporary views of the stakeholders. Journal of Hospitality \& Tourism Education, 14(1), 25-32, https://doi.org/10.1080/10963758.2002.10696721

Chung-Herrera, B. G., Enz, C. A., \& Lankau, M. J. (2003). A competencies model: Grooming future hospitality leaders. Cornell Hotel and Restaurant Administration Quarterly, 44(3), 17-25, https://10.1177/001088040304400302

Cohen, J. (1988). Statistical Power Analysis for the Behavioral Sciences. Lawrence Earlbaum Associates. Hill- 
sdale, $N J, 20-26$.

Collins, J. C., \& Porras, J. I. (2005). Built to Last: Successful Habits of Visionary Companies: Random House.

Cronbach, L. J. (1951). Coefficient alpha and the internal structure of tests. Psychometrika, 16(3), 297-334, http://dx.doi.org/10.1007/BF02310555

Dunleavy, J., Milton, P., \& Crawford, C. (2010). The search for competence in the 21 st century. Quest Journal $2010,2$.

Ellickson, M. C., \& Logsdon, K. (2002). Determinants of job satisfaction of municipal government employees. Public Personnel Management, 31(3), 343-358, https://doi.org/10.1177/009102600203100307

Furnham, A. (1994). Personality at Work: The Role of Individual Differences in the Workplace: Psychology Press.

Golubovskaya, M., Robinson, R. N., \& Solnet, D. (2017). The meaning of hospitality: do employees understand? International Journal of Contemporary Hospitality Management, 29(5), 1282-1304.

https://doi.org/10.1108/IJCHM-11-2015-0667

Hannan, M. T., \& Freeman, J. (1977). The population ecology of organizations. American Journal of Sociology, 82(5), 929-964, https://doi.org/10.1086/226424

Hartle, F. (1995). How to Re-engineer Your Performance Management Process: Kogan Page.

Hulin, C. L., \& Judge, T. A. (2003). Job attitudes. Handbook of Psychology: Industrial and Organizational Psychology, 12, 255-276, https://doi.org/10.1002/0471264385.wei1211

Jang, J., \& George, R. T. (2012). Understanding the influence of polychronicity on job satisfaction and turnover intention: A study of non-supervisory hotel employees. International Journal of Hospitality Management, 31(2), 588-595, https://10.1016/j.ijhm.2011.08.004

Kara, D., Uysal, M., Sirgy, M. J., \& Lee, G. (2013). The effects of leadership style on employee well-being in hospitality. International Journal of Hospitality Management, 34, 9-18, http://dx.doi.org/10.1016/j.ijhm.2013.02.001

Kim, W. G., \& Brymer, R. A. (2011). The effects of ethical leadership on manager job satisfaction, commitment, behavioral outcomes, and firm performance. International Journal of Hospitality Management, 30(4), 1020-1026, http://dx.doi.org/10.1016/j.ijhm.2011.03.008

Ko, W.-H. (2012). The relationships among professional competence, job satisfaction and career development confidence for chefs in Taiwan. International Journal of Hospitality Management, 31(3), 1004-1011. doi: http://dx.doi.org/10.1016/j.ijhm.2011.12.004

Kong, H., Cheung, C., \& Song, H. (2012). From hotel career management to employees' career satisfaction: The mediating effect of career competency. International Journal of Hospitality Management, 31(1), 76-85, https://dx.doi.org/10.1016/j.ijhm.2011.03.002

Königová, M., Urbancová, H., \& Fejfar, J. (2012). Identification of managerial competencies in knowledge-based organizations. Journal of Competitiveness, 4(1), 129-142, https://10.7441/joc.2012.01.10

Lam, W., \& Chen, Z. (2012). When I put on my service mask: Determinants and outcomes of emotional labor among hotel service providers according to affective event theory. International Journal of Hospitality Management, 31(1), 3-11, https://10.1016/j.ijhm.2011.04.009

Lee, C. H., \& Bruvold, N. T. (2003). Creating value for employees: investment in employee development. The International Journal of Human Resource Management, 14(6), 981-1000, https://doi.org/10.1080/0958519032000106173

Locke, E. (1976). The Nature and Causes of Job Satisfaction. Handbook of industry and organizational psychology. Chicago: Ed. In: Rand McNally College.

Lok, P., \& Crawford, J. (2004). The effect of organisational culture and leadership style on job satisfaction and organisational commitment: A cross-national comparison. Journal of management development, 23(4), 321338, https://doi.org/10.1108/02621710410529785

Luthar, B., \& Trdina, A. (2015). Nation, gender, class: celebrity culture and the performance of identity in the balkans. Slavic Review, 74(2), 265-287, https://doi.org/10.1017/s003767790000142x

McClelland, D. C. (1973). Testing for competence rather than for" intelligence.". American Psychologist, 28(1), 1, https://doi.org/10.1037/h0034092

McClelland, D. C. (1998). Identifying competencies with behavioral-event interviews. Psychological Science, 9(5), 331-339, https://doi.org/10.1111/1467-9280.00065

McPhail, R., Patiar, A., Herington, C., Creed, P., \& Davidson, M. (2015). Development and initial validation of a hospitality employees' job satisfaction index: Evidence from Australia. International Journal of Contemporary Hospitality Management, 27(8), 1814-1838, https://10.1108/IJCHM-03-2014-0132

Mihalič, R. (2008). Povečajmo zadovoljstvo in pripadnost zaposlenih [Increasing job satisfaction and engagement of employees]. In: Škofja Loka: Mihalič in partner.

Moolman, H. J., \& Wilkinson, A. (2014). Essential generic attributes for enhancing the employability of hospitality management graduates. Turizam: Znanstveno-Stručni Časopis, 62(3), 257-276.

Müller, R., \& Turner, R. (2010). Leadership competency profiles of successful project managers. International Journal of Project Management, 28(5), 437-448, https://doi.org/10.1016/j.ijproman.2009.09.003

Noe, R. A., Hollenbeck, J. R., Gerhart, B., \& Wright, P. M. (2006). Human Resource Management: Gaining a Competitive Advantage: McGraw Hill.

Nogueira Novaes Southgate, A., \& Mondo, T. S. (2017). 
Perceptions of job satisfaction and distributive justice: A case of Brazilian F\&B hotel employees. Turizam: Znanstveno-Stručni Časopis, 65(1), 87-101.

Okpara, J. O., \& Wynn, P. (2008). The impact of ethical climate on job satisfaction, and commitment in Nigeria: Implications for management development. Journal of Management Development, 27(9), 935-950, https://doi.org/10.1108/02621710810901282

Pan, F. C. (2015). Practical application of importance-performance analysis in determining critical job satisfaction factors of a tourist hotel. Tourism Management, 46, 84-91, https://10.1016/j.tourman.2014.06.004

Paulauskaite, D., Powell, R., Coca-Stefaniak, J. A., \& Morrison, A. M. (2017). Living like a local: Authentic tourism experiences and the sharing economy. International Journal of Tourism Research, 19(6), 619-628, https://doi.org/10.1002/jtr.2134

Potočnik Topler, J. (2017). Communication Skills in the Tourism Sector: The Speech Culture of Tour Guides. Tourism Culture \& Communication, 17(3), 217-223, https://doi.org/10.3727/109830417X15057457661659

Prahalad, C. K., \& Hamel, G. (2006). The Core Competence of the Corporation. In Strategische unternehmungsplanung-strategische unternehmungsführung ( $\mathrm{pp}$. 275-292): Springer.

Rangus, M., \& Brumen, B. (2016). Development of tourism resarch. Teorija in Praksa, 53(4), 929.

Rich, B. L., Lepine, J. A., \& Crawford, E. R. (2010). Job engagement: Antecedents and effects on job performance. Academy of management journal, 53(3), 617635. doi: http://dx.doi.org/10.5465/AMJ.2010.51468988

Santos, M. C., Veiga, C., \& Águas, P. (2016). Tourism services: facing the challenge of new tourist profiles. Worldwide Hospitality and Tourism Themes, 8(6), 654669.

Sarwar, S., \& Abugre, J. (2013). The influence of rewards and job satisfaction on employees in the service industry. The Business \& Management Review, 3(2), 22.

Snell, S. A., Morris, S. S., \& Bohlander, G. W. (2015). Managing Human Resources: Nelson Education.

Spector, P. E. (1997). Job Satisfaction: Application, Assessment, Causes, and Consequences (Vol. 3): Sage publications.

Spowart, J. (2011). Hospitality Students' Competencies: Are They Work Ready? Journal of Human Resources in Hospitality \& Tourism, 10(2), 169-181, https://doi.org/10.1080/15332845.2011.536940

Spruill, M. C. (1976). A comparison of chi-square goodness-of-fit tests based on approximate Bahadur slope. The Annals of Statistics, 4(2), 409-412, http://dx.doi.org/10.1214/aos/1176343418

STAT.SI. (2013). Active population by Labour Force Survey - annually. Retrieved from

http://pxweb.stat.si/pxweb/Database/Demographics/07_labour_force/02_07008_active_pop_
ADS/02_07621_active_pop_ADS_yearly/02_07621_ active_pop_ADS_yearly.asp

Tomaževič, N., Seljak, J., \& Aristovnik, A. (2014). Factors influencing employee satisfaction in the police service: the case of Slovenia. Personnel Review, 43(2), 209227 , https://doi.org/10.1108/PR-10-2012-0176

Tongchaiprasit, P., \& Ariyabuddhiphongs, V. (2016). Creativity and turnover intention among hotel chefs: The mediating effects of job satisfaction and job stress. International Journal of Hospitality Management, 55, 33-40, https://10.1016/j.ijhm.2016.02.009

Torres, N. E., \& Kline, S. (2013). From customer satisfaction to customer delight: Creating a new standard of service for the hotel industry. International Journal of Contemporary Hospitality Management, 25(5), 642659.

Turnšek, M., \& Ladkin, A. (2017). Nova pravila igre za delavce? Airbnb in platformna ekonomija. [Changing Employment in the Sharing Economy: The Case of Airbnb]. Javnost-The Public, 24(SUP 1), S82-S99, https://doi.org/10.1080/13183222.2017.1411570

Tutuncu, O., \& Kozak, M. (2007). An investigation of factors affecting job satisfaction. International Journal of Hospitality \& Tourism Administration, 8(1), 1-19.

Ulrich, D., Brockbank, W., Yeung, A. K., \& Lake, D. G. (1995). Human resource competencies: An empirical assessment. Human Resource Management, 34(4), 473-495, http://dx.doi.org/10.1002/hrm.3930340402

Uran Maravić, M., Križaj, D., \& Lesjak, M. (2015). Innovation in Slovenian tourism organisations. Tourism and Hospitality Management, 21(1), 51-62.

Valentine, S. R. (2001). Men and women supervisors' job responsibility, job satisfaction, and employee monitoring. Sex Roles, 45(3), 179-197, https://doi.org/10.1023/a:1013549710711

van Klink, M. R. d., \& Boon, J. (2003). Competencies: The triumph of a fuzzy concept. International Journal of Human Resources Development and Management, 3(2), 125-137, https://doi.org/10.1504/ijhrdm.2003.002415

Voon, M. L., Lo, M. C., Ngui, K. S., \& Ayob, N. B. (2011). The influence of leadership styles on employees' job satisfaction in public sector organizations in Malaysia. International Journal of Business, Management and Social Sciences, 2(1), 24-32.

Vroom, V. H. (1957). Manage People, not Personnel: Motivation and Performance Appraisal: Harvard Business Press.

Wong, S. C., \& Lee, P. C. (2017). Competencies of training professionals in the Hong Kong hotel industry. Journal of Human Resources in Hospitality \& Tourism, 1-17, https://doi.org/10.1080/15332845.2017.1266872 
Yeh, C. M. (2013). Tourism involvement, work engagement and job satisfaction among frontline hotel employees. Annals of Tourism Research, 42, 214-239, http://dx.doi. org/10.1016/j.annals.2013.02.002

Mitja Gorenak (PhD) is an Associate Professor and Vice Dean for international relations at the Faculty of Tourism at University of Maribor, Slovenia. He has obtained his PhD in Organizational Sciences from the Faculty of Organizational Sciences, University of Maribor. His work he specializes in human resources in tourism sector with special interest in values, competencies and ethical conduct of individuals. For several years, he has cooperated with various organizations in tourism sector helping them in the area of human resources. He is also a licenced tour guide in Slovenia.
Tomi Špindler (M.A.) is a PhD candidate currently working as a Teaching Assistant at the Faculty of Tourism at University of Maribor, Slovenia. His research focus is on values and perceptions of various generations of tourists.

Boštjan Brumen (PhD) is an Associate Professor and Dean of the Faculty of Tourism at University of Maribor, Slovenia. Having obtained his PhD in Computer Sciences and Informatics from the same university. His research interests are mainly focused on the use of information technology in tourism. He is an author and co-author of several books, scientific articles and conference papers. 